\title{
Komunikasi Interpersonal Pekerja Anak yang Dieksploitasi oleh Orang Tua
}

\author{
Novalia, Suzy Azeharie \\ novaliasuryanto123@gmail.com,suzya@fikom.untar.ac.id
}

Fakultas Ilmu Komunikasi Universitas Tarumanagara

\begin{abstract}
This research is titled Interpersonal Communication of Child Labor Exploited by Parents. The aim of the study was to determine the interpersonal communication of child labor that was exploited by parents. This study uses qualitative research methods using the phenomenology approach. Where researchers chose and used semi-structured interviews with five informants. The research data obtained by researchers comes from the results of interviews, observation and literature. This research was carried out with the intention of knowing the interpersonal communication of child labor that was exploited by parents. The theory used by the authors in the study was the theory of interpersonal communication from Richard West and Lynn H. Turner. Then the conclusion of this study is the existence of interpersonal communication between child workers and parents who carry out acts of exploitation verbally and nonverbally.
\end{abstract}

Keywords: Interpersonal Communication, Child Labor, Exploitation, Parents

\begin{abstract}
Abstrak
Penelitian ini mengangkat mengenai komunikasi interpersonal pekerja anak yang dieksploitasi oleh orang tua. Tujuan penelitian adalah untuk mengetahui komunikasi interpersonal pekerja anak yang dieksploitasi oleh orang tua. Penelitian ini menggunakan metode penelitian kualitatif dengan menggunakan pendekatan fenomenologi. Peneliti memilih menggunakan wawancara semi terstruktur terhadap lima informan. Data penelitian yang didapat oleh peneliti bersumber dari hasil wawancara, observasi dan studi pustaka. Penelitian ini dilakukan dengan maksud untuk mengetahui komunikasi interpersonal pekerja anak yang dieksploitasi oleh orang tua. Teori yang digunakan adalah teori komunikasi interpersonal dari Richard West dan Lynn H. Turner. Kesimpulan dari penelitian ini yaitu adanya komunikasi interpersonal antara pekerja anak dengan orang tua yang melakukan tindakan eksploitasi secara verbal maupun nonverbal.
\end{abstract}

Kata Kunci: Komunikasi Interpersonal, Pekerja Anak, Eksploitasi, Orang Tua

\section{Pendahuluan}

Anak merupakan sebuah anugerah dari Yang Maha Kuasa karena pada dasarnya anak yang dilahirkan menjadi hadiah yang sangat berarti bagi orang tua sehingga tidak ada yang boleh merampas kebahagiaan seorang anak termasuk orang tua mereka. Seorang anak seharusnya mendapatkan perhatian, kasih sayang dan pendidikan dari orang tua mereka dan sudah menjadi tanggung jawab orang tua untuk memenuhi kebutuhan dan hak-hak anak mereka.

Idealnya seorang anak mendapatkan hak-hak mereka dari orang tua seperti hak mendapat pendidikan, memperoleh kesehatan serta kasih sayang dari orang tua mereka. Di sisi lain sampai saat ini masih terlihat ada anak-anak yang berada dijalan 
atau tempat keramaian untuk mencari uang. Pada umumnya anak-anak tersebut dieksploitasi oleh orang tua untuk menjadi seorang pekerja anak di jalan. Situasi seperti ini memiliki dampak buruk bagi perkembangan anak secara mental, fisik, dan kehidupan sosial mereka. Undang-Undang No. 23 Tahun 2002 tentang Perlindungan Anak Pasal 59 menyebutkan bahwa Pemerintah dan Lembaga Negara berkewajiban dan bertanggung jawab untuk memberikan perlindungan khusus kepada anak dalam situasi darurat, anak yang berhadapan dengan hukum, anak-anak dari kelompok minoritas dan terisolasi, anak yang dieksplotasi secara ekonomi, seksual dan anak yang diperdagangkan.

Dari wawancara dengan Robet B. Triyana yang merupakan analis pelayanan publik Komnas Perlindungan Anak Indonesia diketahui bahwa tahun 2019 Komnas Perlindungan Anak Indonesia mencatat jumlah pengaduan kasus eksploitasi anak yang masuk melalui pelapor datang langsung maupun melalui surat dan telepon sebanyak 19 kasus. Sedangkan berdasarkan pemantauan melalui media cetak, elektronik maupun online yang dilakukan Komnas Perlindungan Anak Indonesia terdapat 125 kasus eksploitasi anak. Menurutnya, angka eksploitasi terhadap anak masih tinggi yaitu mencapai 67 persen dengan kasus yang berbeda. Data tersebut dari Januari tahun 2019 sampai dengan bulan April 2019.

Dalam eksploitasi terhadap anak menurut Triyana, terdapat bentuk eksploitasi fisik yang merupakan tindakan penyalahgunaan tenaga anak untuk menjadi pekerja anak demi keuntungan orangtuanya atau orang lain seperti menyuruh anak bekerja pada pekerjaan-pekerjaan yang seharusnya belum dijalaninya. Kemudian yang kedua, terdapat eksploitasi sosial yang dapat menyebabkan terhambatnya perkembangan emosional anak. Seperti melontarkan kata-kata yang mengancam atau menakut-nakuti anak, tidak mempedulikan perasaan anak, perilaku negatif pada anak dan mengeluarkan kata-kata yang tidak baik untuk perkembangan emosi anak. Ketiga adalah eksploitasi seksual yaitu terlibatnya anak dalam kegiatan seksual yang tidak dipahaminya. Eksploitasi seksual berupa perlakuan tidak senonoh dari orang lain, kegiatan yang menjurus pada pornografi, perkataan-perkataan porno, menelanjangi anak, prostitusi anak, menggunakan anak untuk produk pornografi dan melibatkan anak dalam bisnis prostitusi. Bentuk eksploitasi di atas juga terdapat dalam Undang-Undang No. 23 Tahun 2002 (wawancara dengan Robert B. Triyana melalui telepon pada tanggal 7 Mei 2019).

Eksploitasi anak menurut Bagong Suyanto merupakan sikap diskriminatif atau perlakuan sewenang-wenang terhadap anak yang dilakukan oleh keluarga ataupun masyarakat (Suyanto, 2010: 132).

Komunikasi interpersonal merupakan komunikasi yang dianggap sebagai salah satu komunikasi untuk membangun dan mempertahankan suatu hubungan yang lebih efektif antara dua orang atau lebih. Komunikasi interpersonal adalah komunikasi antara individu dengan cara tatap muka yang memungkinkan setiap individu dapat menangkap reaksi dari idividu lain secara langsung baik secara verbal maupun nonverbal (Mulyana, 2010: 81).

Dalam penelitian ini penulis tertarik untuk meneliti komunikasi interpersonal pekerja anak yang dieksploitasi oleh orang tua karena penulis ingin mengetahui komunikasi interpersonal yang terjadi antara pekerja anak dengan orang tua di Jakarta Pusat. Rumusan masalah dalam penelitian ini yaitu bagaimana komunikasi interpersonal pekerja anak yang dieksploitasi oleh orang tua? Tujuan penelitian ini yakni ingin mengetahui komuniksi interpersonal pekerja anak yang dieksploitasi oleh orang tua. Penulis menggunakan teori komunikasi interpersonal menurut Richard 
West dan Lynn H. Turner karena penelitian mengenai komunikasi interpersonal pekerja anak yang dieksploitasi oleh orang tua belum pernah ada yang meneliti. Melalui teori yang digunakan penulis ingin mengetahui hubungan serta komunikasi yang terjadi antara pekerja anak yang mendapatkan tindakan eksploitasi yang dilakukan oleh orang tua melalui komunikasi interpersonal yang belum pernah dilakukan oleh penelitian lainnya.

\section{Metode Penelitian}

Dalam penelitian ini penulis menggunakan metode penelitian kualitatif dengan menggunakan pendekatan fenomenologi. Menurut Bogdan dan Biklen, fenomenologi merupakan suatu tipe atau jenis penelitian kualitatif yang berusaha untuk memahami sebuah makna dari suatu peristiwa dan interaksi dalam situasi tertentu. Dalam penelitian fenomenologi selalu difokuskan pada menggali, memahami dan menafsirkan arti fenomena, peristiwa dan hubungannya dengan orang-orang biasa dalam situasi tertentu (Yusuf, 2015:351). Penulis menggunakan metode tersebut karena sesuai dengan perumusan masalah penulis yaitu untuk mengetahui komunikasi interpersonal pekerja anak yang dieksploitasi oleh orang tua.

Subjek dalam penelitian penulis adalah komunikasi interpersonal antara pekerja anak dan orang sedangkan objek penelitian adalah anak dan orang tua. Data yang diperoleh penulis berdasarkan pengumpulan data melalui observasi, wawancara serta studi pustaka. Lima narasumber yang diwawancarai oleh penulis yaitu: Putri A yang merupakan anak yang dieksploitasi, Tiara A yang merupakan anak yang dieksploitasi, Melda Y yang merupakan orang tua dari Tiara A yang melakukan tindakan eksploitasi terhadap Tiara, Sumiyati yang merupakan orang tua dari Putri A yang melakukan tindakan eksploitasi terhadap Putri A, serta Robet B. Triyana selaku Analisis Pelayanan Publik Komnas Perlindungan Anak Indonesia sejak 2013 hingga sekarang.

Dalam membuktikan keabsahan data, peneliti menggunakan teknik keabsahan data dengan teknik triangulasi. Teknik triangulasi merupakan teknik pemeriksaan keabsahan data yang memanfaatkan sesuatu yang lain (Moleong, 2012:230).

\section{Hasil Temuan dan Diskusi}

Berdasarkan hasil wawancara dan pengamatan yang dilakukan oleh penulis terdapat komunikasi interpersonal pekerja anak yang dieksploitasi oleh orang tua. Berdasarkan hasil wawancara penulis dengan Robet B. Triyana, pengertian dari eksploitasi anak adalah suatu kegiatan atau tindakan yang dilakukan oleh orang dewasa atau orang yang memiliki kuasa kepada seseorang yang dianggap lemah untuk suatu kepentingan yang menguntungkan pihak yang punya kuasa. Robet juga menjelaskan bahwa seorang anak dapat dinyatakan dieksploitasi jika anak tidak mendapatkan hak-hak mereka seperti kasih sayang dan kebutuhan mereka serta mendapatkan perlakuan kekerasan dan paksaan. Anak tidak bisa mendapatkan pendidikan atau anak kehilangan hak untuk bermain dengan teman, anak kehilangan hak atas partisipasi, anak dieksploitasi untuk mendapatkan uang oleh orang tua.

Robet juga menyatakan bahwa dalam Undang-Undang No. 23 Tahun 2002 tentang Perlindungan Anak, terdapat tiga jenis eksploitasi anak. Pertama, adanya eksploitasi fisik yang merupakan penyalahgunaan tenaga anak untuk disuruh bekerja demi keuntungan orang tuanya atau orang lain. Kedua, eksploitasi sosial merupakan 
segala sesuatu yang membuat terhambatnya perkembangan emosional pada anak. Ketiga, eksploitasi seksual yaitu melibatkan anak dalam aktivitas seksual dan bisnis prostitusi.

Tiara A dan Putri A merupakan pekerja anak yang dieksploitasi oleh orang tua (ibunya). Tindakan eksploitasi yang dilakukan terhadap anak kandungnya dengan alasan anak ingin bersekolah tetapi tidak ada biaya dan juga beralasan mereka cukup berat memberi uang jajan.

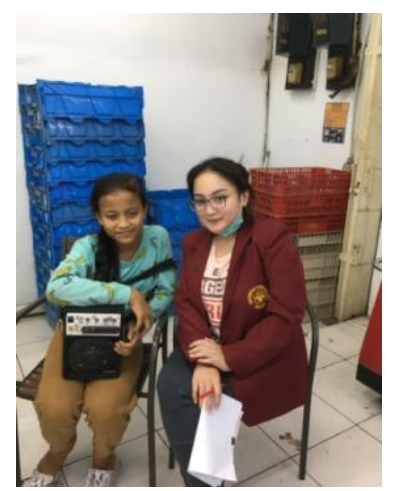

Gambar 1. Foto penulis bersama Tiara A

(Sumber: Dokumentasi Penulis, 2019)

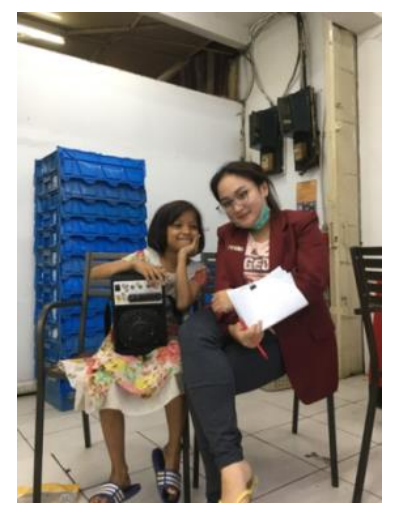

Gambar 2. Penulis bersama Putri A

(Sumber: Dokumentasi Penulis, 2019)

Berdasarkan hasil wawancara yang dilakukan oleh penulis dengan Putri diketahui aktivitasnya sehari-hari. Ia pergi ke sekolah pukul 12.00 WIB dan pulang sekolah pukul 16.30 WIB. Setelah selesai sekolah Putri pulang dan bersiap untuk pergi mengemis di jalan. Biasanya Putri memulai aktivitas sebagai pekerja anak pada pukul 18.00 WIB hingga pukul 22.00 WIB. Ia beristirahat untuk makan pada pukul 19.00 WIB setelah itu melanjutkan untuk mengemis. Ia juga menjelaskan bahwa ia membeli makanan di warteg yang berada di Jalan Biak dan biasanya hanya makan dengan nasi dengan telur balado atau telur goreng dengan tumis sayur. Karena uang hasil mengemis yang diberikan kepada Putri untuk jajan hanya Rp. 20.000, Rp10.000 rupiah digunakan untuk makan malam pada saat ia pergi mengemis dan sisanya ia simpan untuk jajan besoknya di sekolah.

Selain itu, Putri juga menjelaskan bahwa ia pernah sampai dikejar polisi untuk di bawa ke kantor polisi, tetapi ia berhasil kabur dan bersembunyi di belakang mobil seseorang. Putri juga mengatakan dalam menjalankan aktivitasnya sebagai pekerja 
anak, kesulitan yang dialaminya adalah jika sedang hujan maka akan sangat berpengaruh pada uang yang dihasilkan oleh Putri. Ia pernah sakit saat kehujanan dan pernah telat makan karena baru sedikit uang yang didapat. Bila ia mendapatkan sedikit uang ia tidak berani untuk mengeluh kepada orang tuanya karena takut dipukul dan dimarahi oleh ibunya.

Dalam sehari Putri harus menghasilkan uang sebesar Rp 100.000 hingga Rp 150.000 rupiah. Ia harus bekerja mulai dari hari Senin sampai Minggu. Dalam seminggu, Putri boleh tidak bekerja hanya di hari Kamis. Ia mengatakan bahwa ibunya terkadang ikut bersamanya tetapi menunggu di warung yang berada di sekitar tempat biasanya mengemis. Putri mengatakan bahwa penghasilan yang dihasilkan setiap harinya harus ia serahkan ke ibunya dan ia hanya mendapatkan Rp 20.000 untuk jajan.

Pada saat peneliti datang untuk melakukan observasi pada pukul 11.00 WIB peneliti datang dan bertemu dengan Sumiyati, ibu dari Putri. Penulis dipersilakan untuk masuk ke dalam rumahnya. Saat penulis masuk dan dipersilakan duduk, Sumiyati memanggil Putri dan menyuruh Putri agar segera makan dan berangkat sekolah. Putri datang menghampiri penulis dan memberi salam dengan mencium tangan penulis lalu Putri mengambil piring makan siang berupa telur goreng yang telah disiapkan oleh ibunya. Setelah selesai makan, Putri bersiap pergi sekolah sambil menunggu Tiara menjemput untuk pergi bersekolah bersama. Saat akan berangkat sekolah Sumiyati memberitahu Putri bahwa sesudah selesai sekolah ia harus pulang karena harus pergi mengemis dan jangan pergi bermain. Kemudian Putri mengiyakan perkataan ibunya. Penulis kembali ke rumah Putri pada pukul 17.00 WIB dan Putri telah bersiap untuk pergi mengemis sambil menunggu Tiara datang menjemput untuk pergi bersama. Saat penulis duduk bersama Putri yang masih mengenakan seragam sekolah Sumiyati datang lalu berkata bahwa hari ini Putri harus mendapatkan uang lebih karena untuk membantu melunasi uang daftar ulang sebesar Rp 250.000. Putri menyetujui hal tersebut, tidak lama kemudian Tiara datang bersama ibunya menggunakan motor. Kemudian Sumiyati juga menggunakan motornya untuk mengantar Putri sedangkan penulis mengikuti dengan naik ojek online (observasi dilakukan di rumah Putri pada tanggal 24 Juni 2019 pukul 11.00 WIB kemudian dilanjutkan pada pukul 17.00 WIB).

Di sisi lain berdasarkan hasil wawancara yang dilakukan oleh penulis dengan Tiara terungkap aktivitas sehari-hari yang dijalankan oleh Tiara. Ia menjelaskan kepada penulis aktivitas yang dilakukan setiap harinya. Tiap hari ia pergi sekolah pukul 12.00 WIB dan pulang sekolah pukul 17.15 WIB, setelah selesai sekolah Tiara pulang dan bersiap untuk pergi mengemis di jalan.

Tiara biasanya memulai aktivitas sebagai pekerja anak pukul 18.00 WIB hingga pukul 22.00 WIB bersama dengan Putri. Tiara menjelaskan biasanya, ia dan Putri beristirahat untuk makan malam pukul 19.00 WIB di warteg tempat biasa ia mengemis. Ia mengatakan bahwa jatahnya untuk makan di luar hanya satu kali, karena sebelum pergi sekolah ia sudah makan terlebih dahulu. Setelah makan malam, ia melanjutkan mengemis. Ia juga pernah dikejar polisi bersama dengan Putri untuk dibawa ke kantor polisi. Namun, Tiara dan Putri berhasil kabur dan bersembunyi di belakang mobil seseorang dan akhirnya lolos dari kejaran polisi. Sebagai pekerja anak kesulitan yang dialaminya sama seperti yang dialami oleh Putri yaitu jika sedang hujan maka uang yang dihasilkan oleh Tiara sedikit, atau ketika ia sakit.

Tiara tidak berani mengeluh kepada ibunya, karena ibunya selalu mengatakan jika ia tidak mengemis, maka ia tidak akan melanjutkan sekolah lagi. Tiara ingin 
melanjutkan sekolah sampai selesai sehingga ia tetap bertahan meski kadang merasa sangat lelah. Dalam sehari Tiara harus menghasilkan uang sebesar Rp 100.000 hingga $\mathrm{Rp}$ 150.000. Ia harus bekerja mulai dari Senin hingga Minggu. Dalam seminggu, Tiara boleh untuk tidak bekerja hanya di hari Kamis. Setiap harinya, ia bekerja diantar ibunya menggunakan motor ketika waktu pulang Tiara juga pulang bersama dengan ibunya dengan menggunakan motor.

Tiara juga mengatakan bahwa penghasilan yang dihasilkan setiap harinya harus diserahkan ke ibunya semua dan ia hanya mendapatkan Rp 25.000 untuk jajan. Uang hasil mengemis yang diberikan kepada Tiara untuk jajan hanya Rp 25.000, Rp10.000 digunakan untuk makan malam pada saat ia pergi mengemis dan sisanya ia simpan untuk jajan besoknya di sekolah (wawancara dengan narasumber di Jl. Biak, Jakarta Pusat, pada tanggal 28 Mei 20119 mulai pukul 20.00 WIB sampai 22.00 WIB).

Pada saat peneliti datang untuk melakukan observasi pada hari Rabu 26 Juni 2019 pukul 10.30 WIB untuk melakukan observasi secara langsung, peneliti bertemu dengan Melda ibu dari Tiara. Penulis dipersilakan masuk ke dalam rumah. Saat penulis masuk dan dipersilakan duduk, penulis melihat Melda memanggil Tiara Melda lalu berjalan menuju dapur rumahnya. Tidak lama Tiara keluar dari kamar dengan mengenakan seragam sekolah. Kemudian Tiara datang menghampiri penulis dan memberi salam dengan mencium tangan penulis, kemudian Melda datang dan membawakan penulis air minum dan kembali menuju dapur dan membawa makan siang untuk Tiara, ikan goreng dan sayur bayam. Kemudian Melda memanggil Tiara untuk makan. Penulis melihat rumah Tiara terdapat tiga kamar tidur, kamar pertama merupakan kamar orang tua Tiara, kemudia kamar kedua merupakan kamar Tiara, lalu kamar yang ketiga merupakan gudang tempat penyimpanan barang-barang.

Setelah selesai makan waktu menunjukkan pukul 11.30 WIB Tiara bersiap untuk pergi sekolah. Penulis bersama dengan Tiara pergi menuju rumah yang hanya berjarak sekitar enam rumah dari rumah Tiara. Melda memberitahu kepada Tiara bahwa sesudah selesai sekolah ia harus pulang karena harus pergi mengemis dan tidak diperbolehkan pergi bermain karena cuaca hari itu terlihat sedikit mendung dan meminta agar Tiara tidak pulang terlambat agar bisa lebih awal untuk pergi mengemis. Kemudian Tiara menyetujui perkataan ibunya. Setelah sampai di rumah Putri, Tiara memanggil Putri dan mereka pergi sekolah bersama dengan berjalan kaki. Penulis kembali ke rumah Tiara pada pukul 17.30 WIB dan Tiara telah bersiap untuk pergi menjemput Putri dengan mengenakan seragam sekolah. Tiara naik motor dan pergi bersama Melda sedangkan penulis pergi dengan menggunakan ojek online (observasi dilakukan di rumah Tiara pada tanggal 26 Juni 2019 pukul 10.30 WIB kemudian dilanjutkan pada pukul 17.30 WIB).

Di sisi lain observasi yang dilakukan peneliti di lokasi biasanya Putri dan Tiara mengemis. Setelah sampai di Jalan Biak, Sumiyati dan Melda membantu Tiara dan Putri untuk menyebrang jalan, kemudian Putri dan Tiara memulai untuk mengemis. Sekitar pukul 19.00 WIB Putri bersama dengan Tiara menuju warteg untuk makan malam. Penulis melihat Putri makan dengan telur goreng dan tumis kangkung, sedangkan Tiara makan dengan telur balado dengan tumis buncis. Sedangkan Sumiyati dengan Melda duduk di warung kopi yang berada tepat di sebrang jalan tempat Putri dan Tiara mengemis. Kemudian setelah selesai makan malam mereka melanjutkan untuk mengemis, sekitar pukul 20.30 WIB Melda memanggil Tiara dengan cara berteriak dan mengarahkan jarinya ke arah tenda yang berada di samping Tiara. Penulis menanyakan kepada Tiara kenapa ibunya memanggil. Tiara mengatakan bahwa ibunya meminta mereka untuk berpindah tempat. Setelah itu, 
mereka masuk ke dalam tenda makan tersebut. Sekitar pukul 21.55 WIB. Melda bersama Sumiyati menghampiri Tiara dan Putri dan membantu mereka untuk menyebrang jalan sambil menuntun anaknya dan pulang dengan menggunakan motor, penulis pun pulang dengan menggunakan ojek online (observasi penulis pada tanggal 24 Juni 2019 mulai pukul 17.00 WIB hingga pukul 22.00 WIB).

Idealnya seorang anak mendapatkan kasih sayang penuh dari seorang ibu. Dari teori yang digunakan penulis bahwa seorang anak dinyatakan dieksploitasi jika anak tersebut tidak mendapatkan hal-hal sebagai berikut yaitu anak tidak mendapatkan hak-hak mereka seperti kasih sayang dan kebutuhan mereka serta mendapatkan perlakuan kekerasan dan paksaan, anak tidak bisa mendapatkan pendidikan baik adanya paksaan ataupun tidak, anak kehilangan hak untuk bermain dengan teman, anak kehilangan hak atas partisipasi, anak dieksploitasi untuk mendapatkan uang oleh orang tua. Walaupun anak tersebut mendapatkan pendidikan tetapi mereka mendapatkan pendidikan dengan cara harus bekerja sebagai pengemis untuk membantu membayar uang sekolah. Jadi bisa dikatakan jika orang tua mereka tidak memberikan pendidikan kepada anak karena biaya sekolah, anak merekalah yang bayar dengan menjadi pengemis di jalanan.

\section{Simpulan}

Penulis menyimpulkan beberapa kesimpulan yang menjadi hasil dari penelitian penulis sebagai berikut:

1. Komunikasi interpersonal merupakan komunikasi yang terjadi antara dua orang yang dapat dilakukan secara verbal maupun nonverbal

2. Komunikasi interpersonal yang terjadi antara pekerja anak yang dieksploitasi oleh ibunya menggunakan komunikasi verbal dan komunikasi nonverbal. Dengan demikian, komunikasi interpersonal yang digunakan adalah komunikasi verbal digunakan untuk berkomunikasi dan berinteraksi hingga terjadinya eksploitasi, juga dalam kehidupan sehari-hari.

3. Komunikasi interpersonal yang terjadi antara pekerja anak yang dieksploitasi oleh ibunya. Dengan menggunakan komunikasi nonverbal digunakan pada saat orang tua memberikan arahan kepada pekerja anak untuk berpindah lokasi, pada saat ibunya membantu anaknya menyebrang jalan dengan bergandengan pada saat menyebrang jalan.

4. Eksploitasi terhadap anak oleh ibunya dapat dilihat melalui tindakan ibunya yang mengeksploitasi anak untuk menjadi seorang pekerja anak. Berdasarkan jenis eksploitasi terhadap anak dalam Undang-Undang No. 23 Tahun 2002 Tentang Perlindungan Anak, terdapat tuga jenis eksploitasi yaitu eksploitasi secara fisik, eksploitasi secara sosial, dan eksploitasi secara seksual. Dengan demikian berdasarkan hasil dari penelitian penulis kepada narasumber penulis yaitu eksploitasi secara fisik. Eksploitasi yang dilakukan ibunya terhadap anak dengan menjadikan anak mereka seorang pekerja demi kepentingan pribadi. Tanpa memikirkan perasaan dan mental anak yang dieksploitasi.

5. Ibu adalah orang yang rela mempertaruhkan nyawa demi lahirnya sang buah hati. Seharusnya sebagai seorang ibu memberikan yang terbaik untuk anaknya, hal ini berbanding terbalik dengan apa yang diterima oleh pekerja anak yang menjadi narasumber penulis, mereka diharuskan untuk bekerja menjadi pengemis untuk membantu kebutuhan sekolah mereka yang seharusnya sudah menjadi tanggung jawab orang tua untuk memberikan pendidikan kepada anak. Dengan demikian 
berdasarkan hasil penelitian penulis terhadap orang tua dari narasumber peneliti bahwa tidak sepenuhnya orang tua narasumber melaksanakan peran dan tugasnya sebagai orang tua.

6. Seorang anak merupakan keturunan dari hubungan antara seorang laki-laki dengan perempuan. Menurut Undang-Undang Nomor 23 Tahun 2002 yang termasuk anak itu usianya belum mencapai 18 tahun termasuk juga anak yang masih dalam kandungan. Dengan demikian, berdasarkan hasil penelitian yang penulis lakukan adalah narasumber peneliti yang merupakan pekerja anak yang dieksploitasi oleh ibunya tidak mendapatkan perlakuan yang baik yang seharusnya dilakukan orang tua terhadap anaknya seperti memberikan kasih sayang terhadap anak, memberikan pendidikan yang baik, kehidupan yang layak untuk anak. Mereka tidak mendapatkan apa yang seharusnya orang tua berikan kepada anak, melainkan narasumber mendapatkan tindakan kekerasan dari orang tua si pekerja anak, hal tersebut terjadi jika pekerja anak tidak mau pergi untuk mengemis dan saat pekerja anak merasa lelah untuk pergi mengemis.

\section{Ucapan Terima Kasih}

Penulis mengucapakn rasa terima kasih kepada seluruh pihak yang telah membantu serta mendukung penulis selama proses penelitian berlangsung sampai dengan terbitnya publikasi atas hasil penelitian ini selesai.

\section{Daftar Pustaka}

Arikunto, Suharsimi. (2016). Prosedur Penelitian: Suatu Pendekatan Praktik. Jakarta: Rineka Cipta.

AW, Suranto. (2011). Komunikasi Interpersonal. Tangerang : Graha Ilmu.

Bagong, Suyanto. (2010). Masalah Sosial Anak. Jakarta: Kencana.

Budyatna, Muhammad dan Ganiem, Leila Mona. (2011). Komunikasi Antarpribadi. Jakarta: Prenadamedia Group.

Cangara, Hafied. (2012). Pengantar Ilmu Komunikasi. Jakarta: PT Raja Grafindo Persada.

Gunarsa, Singgih D. (1976). Psikologi Untuk Keluarga. Jakarta: Gunung Mulia. Gunawan, Imam. (2014). Metode Penelitian Kualitatif. Jakarta: Bumi Aksara.

H. B, Sutopo. (2006). Metodologi Penelitian Kualitatif. Surakarta: Sebelas Maret.

Handayani, M. (2017). "Pencegahan Kasus Kekerasan Seksual Pada Anak Melalui Komunikasi Antarpribadi Orang Tua dan Anak". Jurnal ilmiah.

Hardjana, M Agus. (2003). Komunikasi Interpersonal dan Intrapersonal. Google scholar.

Herdiansyah, Haris. (2011). Metode Penelitian Kualitatif. Jakarta: Salemba Humanika.

Idrus, Muhammad (2009). Metode Penelitian Ilmu Sosial. Jakarta: Erlangga.

Kurniawati, Nia Kania. (2014). Komunikasi Antarpribadi. Tangerang: Graha Ilmu.

Kuswarno, Engkus. (2009). Metode Penelitian Komunikasi: Fenomenologi, Konsepsi, Pedoman dan Contoh Penelitiannya. Bandung: Widya Padjadjaran.

Liliweri, Alo. (2011). Komunikasi Serba Ada Serba Makna. Jakarta: Kencana.

M. Nasir Djamil, M. Nasir. (2013). Anak Bukan Untuk Dihukum. Jakarta: Sinar Grafika. 
Moleong, Lexy J. (2012). Metodologi Penelitian Kualitatif. Bandung: Remaja Rosdakarya.

Mulyana, Deddy. (2006). Metodologi Penelitian Kualitatif. Bandung: PT Remaja Rosdakarya.

Mulyana, Deddy. (2010). Ilmu Komunikasi Suatu Pengantar. Bandung: PT Remaja Rosdakarya.

Nazir, Mohammad. (2011). Metode Penelitian. Bogor: Ghalia Indonesia.

Saputri, H. (2010). "Eksploitasi Anak Jalanan Sebagai Pengamen di

Kawasan Simpang Lima Semarang”. Jurnal Komunikasi.

Diakses pada tanggal 20 Maret 2019.

Sugiyono. (2014). Metode Penelitian Kuantitatif, Kualitatif, dan R\&D. Bandung: Penerbit Alfabeta.

Sujarweni, Wiratna. (2014). Metodologi Penelitian Lengkap, Praktis dan Mudah Dipahami. Yogyakarta: Pustakabarupress.

Sutopo, Aristo Hadi dan Adrianus Arif. (2010). Terampil Mengolah Data Kualitatif Dengan NVIVO. Jakarta: Prenada Media Group.

Suyanto, Bagong dan Sutinah. (2006). Metode Penelitian Sosial Berbagai Alternatif Pendekatan. Jakarta: Kencana Prenada Media Group.

Undang-Undang No. 23 Tahun 2002. Tentang Perlindungan Anak.

Undang-Undang nomor 23 tahun 2002. Mengenai Perlindungan Anak (UU no 23, 2002 pasal satu ayat satu). 